To Cite This Article: Yıldırım, S. \& Ünlü, M. (2021). Evaluating in-service GIS training for geography teachers based on G-TPACK model. International Journal of Geography and Geography Education (IGGE), 44, 112-123.

\title{
EVALUATING IN-SERVICE GIS TRAINING FOR GEOGRAPHY TEACHERS BASED ON G-TPACK MODEL ${ }^{1}$
}

Salih YILDIRIM²

Mehmet ÜNLÜ3

\begin{abstract}
Many different barriers have been identified which limit integration of spatial technologies into secondary school education. Because of these challenges teachers tend to concentrate traditional teaching methods instead of removing obstacles on using spatial technologies. However, we may remove physical (lack of hardware, software) and technical (lack of computer) barriers in terms of requirements of geography teachers. Geography teachers who can combine their technological skills with pedagogical and field knowledge are the ones who meets today's educational needs. It is necessary to organize in-service training (IST) activities that can meet today's needs in geography education, prepared in line with the needs of teachers and helpful in developing their technological competencies, to which they can participate voluntarily. The aim of this study was to develop, implement and evaluate in-service training GIS course among geography teachers using an open source software, free data and geographical technological pedagogical content knowledge (G-TPACK) model. The research employed both qualitative and quantitative research methods and techniques. Our study proved that in-service GIS training which was admired to attend by teachers according to the needs analysis, have improved their skills and knowledge.
\end{abstract}

Keywords: Geography Teaching, In-Service Training, G-TPACK Model, QGIS

\footnotetext{
${ }^{1}$ This study is derived from the doctoral thesis titled "Developing, implementing and evaluating in-service training program for geography teachers based on G-TPACK model using open source GIS software and free data".

${ }^{2}$ Correspondece to: Assist. Prof., Marmara University, Atatürk Education Faculty, istanbul, TURKEY., https://orcid.org/0000-0003-4952-3788., salih.yildirim@marmara.edu.tr

${ }^{3}$ Prof., Marmara University, Atatürk Education Faculty, , i̇stanbul, TURKEY., https://orcid.org/0000-0001-8023-2976., munlu@marmara.edu.tr
} 


\section{INTRODUCTION}

Spatial technologies are defined as technologies that enable visualization, mapping, measurement, spatial analysis and finding a route (Metoyer, Bednarz, and Bednarz, 2015). Spatial technologies have been integrated into geography curriculum of countries such as China, Denmark, Japan, Taiwan, and US (Hong, 2015). Studies reveal that spatial technologies should be included in geography education (Johannson, 2006; Kerski, 2008; Jekel, 2008). The positive impact of using spatial technologies among the students of secondary schools has already been proved by some experimental studies. (Patterson, Reeve, and Page, 2003; Bednarz, 2004; Favier and Schee, 2014). In addition, many studies emphasized that students who have the ability to use spatial technology tools can improve their spatial thinking skills (Nielsen, Oberle, and Sugumaran, 2011; Metoyer, 2014; Kerski, 2008).

Geographic technologies are becoming popular and widely used day by day, but integration of these technologies into secondary education classes is inefficient. According to the literature, there are some basic reasons for not using spatial technologies in secondary education: (1) inadequate of the relevant curriculum, (2) software complexities, (3) limitations in school technologies and (4) insufficient teacher training strategies (Milson and Roberts, 2008; Doering and Veletsianos, 2007). Researchers Ye, Brown, and Harding (2014) focused on uncovering the reason and identified the limitations of GIS. They identified the limitations of GIS software, the scarcity of accessible data and the obstacles to create a cloud-based infrastructure. From this point of view, teachers can use open source software to expand the use of GIS such as QGIS which has become the most widely used free and open source software lately (Rossetto et all., 2018).

One of the models that emerged by integrating technological knowledge into pedagogical and field knowledge is the technological pedagogical content knowledge (TPACK) model (Doğru and Aydın, 2017; Doering et all., 2014; Kabakçı Yurdakul, 2011). The origin of the model is based on Shulman's $(1986,1987)$ pedagogical content knowledge (PACK) studies (Kaleli Yılmaz, 2015; Hong and Stonier, 2015). Technological knowledge, which is considered as an important part of contemporary education systems, has also been integrated with PACK by Mishra and Koehler's (2006) study. Necessity of technology integration into pedagogical field knowledge turned into a natural process thanks to increasing technology use in education throughout the world. (Hong and Stonier, 2015). As time progressed, Doering and Veletsianos (2008) have proposed the G-TPACK model that was stated that it has critical importance on design and improvement of geography teacher education.

Many geography teachers continue to carry out the training process with a traditional manner in Turkey. Geography teachers continue to conduct their lessons dependent on the textbook pedagogy instead of using digital resources that they should use. This situation is unsuitable for the spirit of geography curriculum and geography teacher competencies determined by the Ministry of National Education (MEB) (Öztürk and Eroğlu, 2013). Moreover, the steps taken by the MEB to solve the emerging problems revealed the insufficiency of in-service training courses offered to teachers (Güven, 2010). Babacan and Özey (2016), determined the subjects which may be necessary for in-service trainings in Turkey. Accordingly, teachers wanted to expand their information and skills on the ability of teaching via GIS. A similar study was conducted by Artvinli (2010) indicated that GIS is the most requested subject for in-service training by in-service teachers. Taking into account all of these, teachers need in-service training programmes in order to not just develop their spatial skills but also expand their use of spatial technologies effectively in their geography lessons. Within this context, the study aims to develop, implement and evaluate in-service training course that are depended on free software, data, and GTPACK model. Shortly, these are the research questions that we sought to understand and find an answer specifically:

- Research Question 1: What are the needs of geography teachers regarding in-service GIS training?

- Research Question 2: How is the effectiveness and evaluation of the in-service training?

\section{In-Service Training and GIS Using in Turkey}

In Turkey, In-Service Training (IST) is provided by the Supporting and Monitoring Vocational Development Department under the Teacher Training and Development General Directorate. This department, which has been providing trainings since 1960, carried out 84,188 training activities centrally and locally in the 5-year period covering the years 2010-2014, in which 2,061,489 people participated. The department conducts these activities in cooperation with the central and provincial departments of the Ministry, the Council of Higher Education, universities, and other public and private institutions, as well as with non-governmental organizations and foreign cultural centers (MEB, 2021). In addition, distance education activities have started since 2005 for a faster and more effective education process.

In Turkey, it is compulsory for teachers to attend IST compatible with their respective fields. In the USA and Switzerland, teachers must receive certain professional development training in order to be able to continue teaching. In Germany, France, and Japan, participation in IST is required by law (YazıCI and Gündüz, 2011). So, teachers are obligated to participate in IST activities in many developed countries. Nevertheless, in the USA, teachers who participate in IST receive 
increased salaries, and similarly, IST participation is a determinant factor in terms of the seniority of teachers in England. In Turkey, teachers who participate in IST can gain an advantage in terms of transfer and appointments (YazICI and Gündüz, 2011). To ensure the professional development of teachers, IST activities should be obligatory. However, teachers should be able to choose courses they will attend voluntarily among the compulsory IST courses. In other words, obligating teachers to attend IST courses they are not interested in is not a right approach.

Developments in different areas of the geography discipline require a transformation of teachers' knowledge, attitudes, and behaviors. These developments amplify the importance of IST courses and shape the content of field trainings of different disciplines. For example, while GIS was not utilized in geography teaching half a century ago, today, it is among the most important skills a geography teacher should have. Technological developments affect teachers first and then students. Teachers who prefer IST courses on these developments utilize the knowledge they gain in such trainings in their classes. There are many subjects of geography courses/seminars held centrally by the Ministry of National Education between 2001 and 2019. Only seven of these activities aim to encourage the use of technology in geography courses. Therefore, there is a need to organize various courses on subjects involving technology training.

Before 2005, education programs organized by the Ministry of National Education in Turkey were based on different educational approaches. Paradigmatically, the Geography Course Curriculum (GCC), which was renewed in 2005 and revised in later years, has been addressed in line with the needs of our day and has a constructivist, student-centered structure (Balcı, 2012). GCC, using a location-based approach, aims to gain students' geographic awareness of Turkey and the world, as well as geographic knowledge that they can effectively use in their daily lives after they graduate. GIS has a substantial potential that can meet the needs of the GCC. Unlocking this potential will surely lead to the elimination of barriers and effective teacher training.

There are differences in the learning styles of the new generation students compared to the previous generations. The students of the new generation are referred to as "born digital" ( $\mathrm{Ng}, 2012)$. Although it would not be right to call an entire generation digital-born due to opportunity gaps, it is possible to say that most of the new generation has strong ties with the digital world. Teachers who correctly estimate the cognitive levels of students, deliver lectures in line with their readiness, utilize examples, and use different teaching strategies can transfer information to students in a more qualified way (Uşak, 2009). Geography teachers who can combine their technological skills with pedagogical and field knowledge are the ones who possess the aforementioned competencies.

Considering all the variables mentioned above, it is necessary to organize IST activities that can meet today's needs in geography education, prepared in line with the needs of teachers and helpful in developing their technological competencies, to which they can participate voluntarily. We believe that this study will be an important step to fill this existing gap.

\section{METHODS}

\section{Development of In-Service Training Program}

Many models are used in the design, implementation, and evaluation of IST courses. In this study, a system approach model developed by Dick and Carey in 1978, which suggests all elements to work together to achieve the goal, was preferred (Figure 1). The steps of the model are discussed in detail below. 


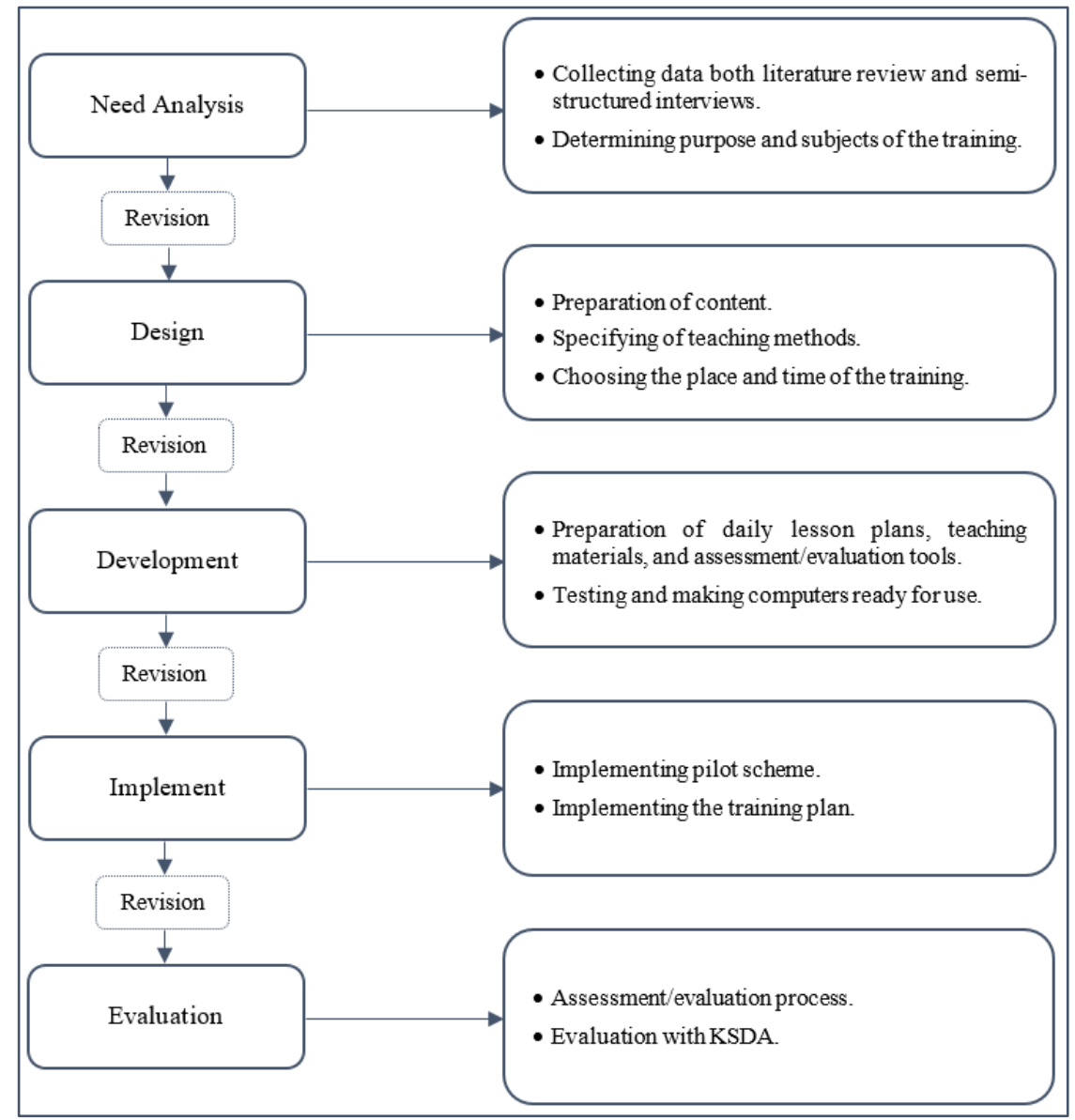

Figure 1: Five Steps of Systems Approach Model

\section{Needs Analysis}

Needs analysis plays an important role in the design of IST programs as it helps to determine the purpose and content of the training (Chunling, 2015). Professionals who design the training are responsible for planning the IST in line with the needs of the participants. Even if all the remaining steps of the IST program, developed without a needs analysis, are designed correctly, the foundation of the education would be built incorrectly as the program cannot predict the training needs. Needs analysis determines where and what kind of training program is needed and the criteria to guide program evaluation.

The data for this part of the study were obtained from semi-structured face-to-face interviews. Probing questions were added to the interview questions prepared by the researcher, in line with the suggestions of three field experts. In order to test the understandability of the form, a pilot interview was held with 2 teachers, and the form was given its final form. The interviews lasted between 15 to 20 minutes and were recorded with an audio recorder, with the consent of the participants. The qualitative data analysis software MAXQDA was used in the analysis of the data. Ten teachers who participated in the interviews were given the codes T1, T2, T3, T4, T5, T6, T7, T8, T9, and T10. By listening to the records obtained, transcripts were created from the answers given by the teachers, and these transcripts were subjected to content analysis. The purpose of content analysis is to gather and interpret similar data within the framework of certain themes (Yıldırım and Şimsek, 2016). The first stage of content analysis consists of coding the data. The coding type referred to as "coding within a conceptual framework" was preferred in this study. Detailed coding has been made by creating a general conceptual framework according to this coding type. In the second stage, codes similar to each other were brought together and integrated into themes covering these codes. In the third and last stage, the data obtained were explained systematically and the statements of the participants were given by means of certain prominent sample quotations.

\section{Design}

The design stage is where the development strategy is created based on the needs analysis data, and how the goals will be achieved is determined. In the design stage, the target behaviors that are planned to be acquired, the content of the 
course, teaching methods, learning activities, and where and when the course will be held are determined. During the design of the IST program, not only the opinions of the participants but also other IST courses they have attended were examined. For the content of the course, various sources were explored, GCC was reviewed, the content of the ISTs attended by teachers related to GIS was examined, and how GIS was used in geography courses was discussed. Since the IST required an easily accessible GIS laboratory, the study was carried out on a university campus located in the district center. A 30-hour in-service training program, which was accepted by the Provincial Directorate of National Education and included in the annual plan, was prepared.

\section{Development}

Development stage is where evaluations and corrections regarding the design stage are made and all materials to be used in the training are prepared. In this section, all processes of the design stage were reviewed in line with the objectives of the IST course program. A teacher's guide for the IST program was prepared to be used during the explanation of the course content to teachers. The QGIS software was installed on the computers to be used by the participants, and the websites to be visited during the training program to access free GIS data were determined. After the course content was finalized, daily schedules were prepared to be distributed to the participants. Afterward, the venue where the training would be held was made ready to host the IST program. The tools and equipment to be used were checked, the technical problems were eliminated by the researcher, and necessary measures were taken to ensure that each participant had a computer.

\section{Implement}

This part of the research consists of two implementations, namely the pilot and the main implementation. The pilot study served to take measures against the problems that may arise in the actual implementation. In order to determine whether the implementation was effective or not, observation notes were taken by the researcher, and the opinions of the participants were noted. Important changes were made in the IST course program in line with the observation notes and the opinions of the participants, as follows:

- Although the theoretical content of the program was sufficient, it was seen that there is little practical experience. Therefore, the number of activities was increased from 14 to 22.

- In line with the teachers' request, the duration of activities was increased.

- During the pilot implementation process, the prepared training guide was distributed to the teachers. It was observed that the teachers did not bring the distributed guides to the courses on some days. In order to address this problem, it was decided to distribute the training guides to teachers on a daily basis in modules.

- It was determined that the multiple-choice questions were insufficient in terms of measuring the achievements of the course; so, evaluation was decided to be made with open-ended questions similar to the activities.

With the pilot implementation, the structural and content arrangements of the course were completed and the actual implementation phase started. The main implementations were carried out between 10:00 and 16:00 every weekday. Participants of the implementation were 14 geography teachers working in 9 schools in the Kadıköy District of Istanbul.

\section{Evaluation}

The evaluation stage consists teachers' evaluation of the program and pre-test, post-test results. The main implementation was evaluated using a 45-question questionnaire consisting of rating, classification, and open-ended questions. In the evaluation of the course content and its implementation, the options insufficient (1), partially insufficient (2), acceptable (3), partially sufficient (4) and sufficient (5) were presented. In the evaluation of the course organizations and the practitioner, as well as the overall evaluation of the program, the options strongly disagree (1), disagree (2), partially agree (3), agree (4), and strongly agree (5) were presented. In order to measure the effectiveness of the implementation, a pre-test and a post-test were performed and SPSS 25 package software was used in the analysis of the data.

Necessary precautions and executing all the phases of the study objectively have been taken into account in particular to ensure the validity and reliability of this research. Meanwhile, participants informed before the study and their approvals to attend the research received in advance. During collecting the data from participants, interviews were ensured not to be interrupted. After the data collected, themes and codes were created reading at least five times. The reliability rate found according to the percentage agreement method of Miles and Huberman (1984). The reliability calculated as $85 \%$ by dividing the number of agreements by the total number of agreements plus disagreements (Table 1). The rates above $70 \%$ is considered to be reliable by Miles and Huberman (1984). 


\begin{tabular}{|l|l|}
\hline \multicolumn{2}{|c|}{ Table 1: Reliability Method } \\
\hline \multirow{2}{*}{ Reliability= } & Number of Agreements \\
\cline { 2 - 2 } & Total Number of Agreements + Disagreements \\
\hline
\end{tabular}

Reliability coefficients of each part of KSDA were given in Table 2., reliable and highly reliable values could be seen by looking at the coefficients in Table 2. The average of all classifications is 0.74 .

\begin{tabular}{|l|l|}
\hline \multicolumn{2}{|c|}{ Table 2: Reliability co-Efficient of KSDA } \\
\hline Classification of Likert Scales According to KSDA & Cronbach's Alpha \\
\hline Evaluation of Course Content / 5-Point Likert Scale & 0,683 \\
\hline Evaluation of the Course Implementation / 5-Point Likert Scale & 0,713 \\
\hline Evaluation of the Course Organization / 5-Point Likert Scale & 0,695 \\
\hline Evaluation of the Course Practitioner / 5-Point Likert Scale & 0,774 \\
\hline Overall Evaluation of the Course / 5-Point Likert Scale & 0,834 \\
\hline
\end{tabular}

\section{RESULTS}

\section{Need Analysis Results}

6 themes emerged as a result of the interviews conducted with geography teachers on the use of free G-TPACK-based GIS software (Table 3).

\begin{tabular}{|c|c|c|c|c|c|}
\hline THEMES & CATEGORY & CODES & PARTICIPANT & $f$ & $\%$ \\
\hline \multirow{6}{*}{$\begin{array}{l}\text { The purpose of } \\
\text { using GIS by } \\
\text { teachers and its } \\
\text { frequency }\end{array}$} & \multirow{2}{*}{ Using enough } & Presentation & $\mathrm{T} 1,3$ & \multirow{2}{*}{3} & \multirow{2}{*}{30} \\
\hline & & Thesis writing & $\mathrm{T} 2$ & & \\
\hline & Using occasionally & Lack of technical knowledge & T4 & 1 & 10 \\
\hline & \multirow{3}{*}{ Nonuse } & Lack of infrastructure & $T 6,8,9$ & \multirow{3}{*}{6} & \multirow{3}{*}{60} \\
\hline & & Lack of technical knowledge & $\mathrm{T} 5,7,10$ & & \\
\hline & & Attitude of administrators & T9 & & \\
\hline THEMES & CODES & & PARTICIPANT & $f$ & $\%$ \\
\hline \multirow{6}{*}{$\begin{array}{l}\text { The reasons of } \\
\text { teachers for seeing } \\
\text { GIS as required in } \\
\text { their lessons }\end{array}$} & \multicolumn{2}{|c|}{ Increasing the effectiveness of teaching } & $\mathrm{T} 1,2,4,5,6,7,8,9,10$ & 9 & 35 \\
\hline & \multicolumn{2}{|c|}{ Using in classroom activities } & $\mathrm{T} 1,4,5,7,8,9$ & 6 & 23 \\
\hline & \multicolumn{2}{|c|}{ Spatial analysis } & $\mathrm{T} 1,2,6,9$ & 4 & 16 \\
\hline & \multicolumn{2}{|c|}{ Representation of geographical distribution principle } & $\mathrm{T} 1,3,4$ & 3 & 11 \\
\hline & \multicolumn{2}{|c|}{ Using as a material in lessons } & $T 1,3,9$ & 3 & 11 \\
\hline & \multicolumn{2}{|c|}{ Using in projects } & $\mathrm{T} 2$ & 1 & 4 \\
\hline \multirow{3}{*}{$\begin{array}{l}\text { In-service training } \\
\text { based on G-TPACK } \\
\text { model }\end{array}$} & \multicolumn{2}{|l|}{ Holistic effect } & $\mathrm{T} 1,2,3,4,5,6,7,9,10$ & 9 & 60 \\
\hline & \multicolumn{2}{|c|}{ Facilitating the course process } & $\mathrm{T} 5,6,7,8$ & 4 & 27 \\
\hline & \multicolumn{2}{|c|}{ Updating teacher's knowledge } & $\mathrm{T} 2,5$ & 2 & 13 \\
\hline \multirow{4}{*}{$\begin{array}{l}\text { Use of open source } \\
\text { GIS software and } \\
\text { free data in in- } \\
\text { service training }\end{array}$} & \multicolumn{2}{|c|}{ Education tools should be free of charge } & $\mathrm{T} 1,2,3,4,6,7,8,9,10$ & 9 & 36 \\
\hline & \multicolumn{2}{|c|}{ The widespread use of GIS } & $\mathrm{T} 1,2,3,5,6,7,8,9,10$ & 9 & 36 \\
\hline & \multicolumn{2}{|c|}{ Difficulties of using shareware } & $\mathrm{T} 1,2,4,9,10$ & 5 & 20 \\
\hline & \multicolumn{2}{|c|}{$\begin{array}{l}\text { Software simplification and adaptation into geography } \\
\text { education }\end{array}$} & T8, 9 & 2 & 8 \\
\hline \multirow{3}{*}{$\begin{array}{l}\text { In which subject } \\
\text { teachers need GIS } \\
\text { more }\end{array}$} & \multicolumn{2}{|c|}{ The need for GIS in every subject of geography } & $\mathrm{T} 1,2,6,7,8,9,10$ & 7 & 47 \\
\hline & \multicolumn{2}{|c|}{ The need for GIS for some subjects of geography } & $\mathrm{T} 1,3,4,5,8,9,10$ & 7 & 47 \\
\hline & \multicolumn{2}{|c|}{$\begin{array}{l}\text { Determining the needs according to teacher } \\
\text { competencies }\end{array}$} & T9 & 1 & 6 \\
\hline \multirow{3}{*}{$\begin{array}{l}\text { Suggestions for the } \\
\text { course program to } \\
\text { be more beneficial }\end{array}$} & \multicolumn{2}{|c|}{ Course time } & $\mathrm{T} 1,2,3,4,5,6,7,8,9,10$ & 10 & 23 \\
\hline & \multicolumn{2}{|c|}{ Course location } & $\mathrm{T} 1,2,3,4,5,6,7,8,9,10$ & 10 & 23 \\
\hline & \multicolumn{2}{|c|}{$\begin{array}{l}\text { Recommendations regarding the theoretical } \\
\text { information and practice }\end{array}$} & $\mathrm{T} 1,2,3,4,5,6,7,8,9,10$ & 10 & 23 \\
\hline
\end{tabular}

Based on the use of frequency and reasons for using the GIS, it can be said that establishing a technological infrastructure for GIS at schools and training teachers on the technical issues related to GIS will increase its use. However, although GIS seems to be an important part of the geography discipline, its use in courses is quite problematic. Some of the statements of the participants that support the conclusions regarding the first theme are as follows:

"I have not had the opportunity to use GIS until today because the technology infrastructure at the school where I work is insufficient." (T6) 
"I used GIS years ago. However, I am currently not using it. Therefore, I could not catch up with the latest versions of the software. During lectures, we mention GIS and give examples of current applications. However, I am not very competent in using it. I cannot make my students use it, either." (T7)

Teachers finding GIS necessary to be used in their courses is determined as the second theme. Almost all participants emphasized the importance of using GIS during geography courses. Accordingly, it can be said that maps produced with GIS can contribute to the permanent learning of students and enrich the course in terms of materials. GIS enables students to meet the needs of the technology age in which they were born and raised. Some of the statements of the participants that support the conclusions regarding the theme are as follows:

"The use of visuals through GIS makes geography courses more interesting. Today's students are very techsavvy. Therefore, if you reach out to these students via technology, even if they are not interested in the subject, they will be curious about what they are looking at. Smart students will go one step further and the uninterested students will become curious of the topic." (T9)

"Students are the natives of digital age. We are, on the other hand, are digital immigrants. Since students are adept at technology, they can analyze digital data using GIS." (T1)

The third theme reveals the importance of the need for a model that combines technology, pedagogy, and content knowledge in geography teaching. G-TPACK model addresses issues with a holistic approach and appeals to more students. This model brings the use of technology into prominence. It can be said that today's students are apt to learning with technology. Besides, teachers see the C-TPACK model as an important advantage in improving themselves. Some of the statements of the participants regarding the theme are as follows:

"I was recently promoting a theoretical technology model in my class. One of the smart students asked me when the class would start. In other words, what we need to understand from here as teachers, is that we need to use technology-based materials in the lesson alongside theoretical knowledge." (T1)

"It would be advantageous. Here's why: The world of technology is vast. Unless you add pedagogical knowledge there, you cannot present that technology to the student. Of course, field knowledge is indispensable as well. These three represent the pillars of a structure. If one of the three is missing, the structure will fail. Therefore, it will be very beneficial to utilize all three together." (T8)

The use of open source GIS software and free data was determined as the fourth theme. Teachers support the use of free educational material. Some teachers mentioned the difficulties they encountered while using paid GIS software. It has also been revealed that teachers sometimes use cracked software but experience difficulties in obtaining data. This situation may adversely affect the sustainability of GIS usage. The provision of free educational material may significantly favor the widespread use of GIS in geography teaching. Another remarkable finding is that most teachers do not have any knowledge of using free GIS software. In developing countries such as Turkey, where education support and educational services significantly differ compared to developed countries, the free access to education materials would eliminate one of the biggest obstacles towards the widespread use of these materials. Some of the statements of the participants regarding theme four are as follows:

"Having to pay for software was a problem during the undergraduate education, too. It would be great if the software was free. Even if we use crack software, finding data is very difficult. If I am to use this software during education, it should be granted to me in some way. I definitely prefer the data and software to be free." (T4)

"If it was a free software, students could also use it for their project assignments. Also, when data is available as well, students can graph and map the data and can utilize them more frequently. I believe many teachers would want this. These courses are already the courses we want and expect. Once the software is free, there will be many who would use it." (T3)

"Last week when I was preparing class material, I could not even create a map of in Turkey using ArcGIS software. I encountered an error in the cracked software I previously installed." (T1)

"I had to illegally crack ArcGIS to use the software. This is neither ethical nor pleasant both for me and the company." (T4)

The fifth theme determines the reasons in which subjects GIS is needed more. These reasons are as follows; the need for GIS in every subject, the need for GIS particularly in some subjects, and the determination of the need according to the competence of the teacher. When evaluated within the scope of the dispersion principle, it is possible to say that GIS can 
be used in every subject in the geography course without distinguishing physical and human, and the use of GIS cannot be limited to the subject. Some of the statements of the participants regarding the theme are as follows:

"It would be helpful for students to create their own maps or make three-dimensional spatial analyses from numerical data, especially in terms of their knowledge on contours and maps, which are among topics about which the national education curriculum suggests to do activities about. Also, GIS can be used for exploring solutions for environmental problems and developing projects for this goal." T5

"GIS can be used especially during 9th-grade geography lessons, in the subject of Turkey's climates, to create climate maps. Again in the 12th grade, GIS can be used in regional geography subjects. I think that especially 9th and 12th-grade subjects are more prone to GIS. It can be used in the 9th grade to attract the attention of the students, and in the 11th and 12th grades to achieve high-level learning. "T10

In the last theme, suggestions of the geography teachers for the course program to be more beneficial were determined. It was seen that these suggestions are regarding the time of the course, the venue of the course, and theoretical knowledge and practical application. According to the results, it is prominent to conduct the IST program at a central location during the seminar period. The participants stated that the program should include more practical application than theoretical training.

\section{Implementation and Evaluation Results}

The effectiveness of the IST course regarding the C-TPACK model-based open source GIS software and free data, with the participation of 14 teachers, was determined through the pre-test and post-test. The teachers scored an average of 40 points from the pre-test and 80 points from the post-test. The effectiveness of the course, or in other words, the differentiation of the results obtained from the pre-test and the post-test, is understood from the linear relationship between the two variables being $\mathbf{0 . 6 0}$. This result is an indication that the course was effective (Table 4).

\begin{tabular}{|c|c|c|c|c|c|c|c|c|}
\hline \multicolumn{8}{|c|}{ Table 4: The Average Scores of Teachers from The Pre- and Post- Tests } \\
\hline \multicolumn{3}{|c|}{ Pre-Test } & \multicolumn{3}{c|}{ Post Test } & & \multicolumn{3}{c|}{ Change } \\
Questions & $\begin{array}{c}\text { Knowledge } \\
\text { Questions }\end{array}$ & $\begin{array}{c}\text { Grades in } \\
\text { Total }\end{array}$ & $\begin{array}{c}\text { Map Based } \\
\text { Questions }\end{array}$ & $\begin{array}{c}\text { Knowledge } \\
\text { Questions }\end{array}$ & $\begin{array}{c}\text { Grades in } \\
\text { Total }\end{array}$ & $\begin{array}{c}\text { Map Based } \\
\text { Questions }\end{array}$ & $\begin{array}{c}\text { Knowledge } \\
\text { Questions }\end{array}$ & $\begin{array}{c}\text { Grades in } \\
\text { Total }\end{array}$ \\
\hline 22 & 58 & 40 & 68 & 92 & 80 & +46 & +22 & +40 \\
\hline
\end{tabular}

The evaluation of the program was carried out using the end-of-course evaluation questionnaire. The questionnaire consists of 5 parts, namely the evaluation of course content, the evaluation of course implementation, the evaluation of course organization, the evaluation of the practitioner, and general evaluation. Regarding the content of the course, the participants found the distribution of subjects and the course's purpose sufficient. Detailed information about the content of the course was given by the researcher and the opinions of the teachers were noted. A contribution was made to the improvement of the course by providing additional information to the teachers.

Factors such as the inclusion of applied activities in the course, the existence of an environment of mutual interaction, and the creation of an environment of tolerance were effective in shaping the teachers' positive thoughts about the implementation of the course. It was concluded that teachers want to practice more, and the duration of the IST course and the number of IST course programs for geography should be increased. Teachers especially responded positively to QGIS being an open-source software and that many geographic data can be downloaded for free. It was observed that teachers' opinions about technological applications have changed in a positive direction. It was determined that teachers want to conduct applications for students and that they realized they could improve themselves individually. Materials and activities related to each topic were prepared by the researcher before the program. After the sessions were carried out, each teacher was asked by the researcher whether they could do the activity or not to ensure no teacher fell behind. If teachers could not keep up with the practitioner, additional time was given to the teachers and efforts were made to address their shortcomings during breaks or at the end of the course. In cases where the researcher could not offer assistance, the teachers who successfully performed the activity helped their colleagues. The participants appreciated that the program was held specifically for geography teachers and that the program practitioner was also a geography educator.

The organization to coincide with an IST period, the selection of a GIS laboratory that is located in the center of the district, and the arrangement of food and beverage organizations played an important role in the teachers' finding the organization of the course sufficient. It was welcomed by the teachers that the practitioner arranged tea-coffee and foodbeverage services before the sessions. In fact, in the following days, with the contribution of the teachers, lunches were 
eaten all together without the need to stay in the classroom. Such fine details, which allowed the creation of a friendly environment, were admired by the participants.

The fact that the course practitioner determined the needs of teachers for the IST program played an important role in the teachers' expressing positive opinions. The successful conduct of the IST program was made possible by carrying out a needs analysis in line with inputs from participants prior to the actual IST and preparing a thorough and rich course plan accordingly, as well as the researcher taking some precautions before the actual implementation of IST. It was noted that when the practitioner makes all the financial and moral efforts he/she can do for the efficiency of the course, even the small mishaps that may arise can be tolerated by the teachers. The practitioner spent time with the participants, even during the breaks, and made efforts to eliminate the deficiencies before starting each day. For example, the practitioner realizing that computers occasionally slowed down on the first day spared time to solve this problem at the end of the course that day. It was observed that the slowdown problem did not re-occur in the following days.

The IST program was found successful by participants in general. It is thought that creating an IST program content in accordance with the participants' expectations, providing participants with material regarding the program content, and creating a medium of discussion for participants where they can exchange ideas about the program played an important role in their satisfaction. Participants' readiness may be low due to various reasons, but it was seen that teachers can carry out many activities in their courses when they learn how to use GIS. Although the practitioner's GIS experience is important, the participants' field knowledge and experience in education are also very important. During the implementation, with the combination of these two important variables, important prospective gains were achieved in terms of the use of GIS in geography courses. For example, in a session, a participant stated that he wanted to have his students do an orienteering activity and while doing this, he needed custom-made maps.

The WhatsApp group created before the beginning of the IST program was not closed after the end of the program upon the participants' request. It was observed that the teachers acted together for different activities through the group. It was seen that, apart from all this positive feedback, there were also negative opinions regarding the venue, the computers' performance, and the time of the sessions. In terms of the time of the IST, some participants stated that "the course should take place at a more convenient time." However, the time of the course was determined after an exchange of ideas was made with the participants on the matter. It was observed that despite this, there were participants who wanted the course to be carried out at a more appropriate time.

\section{DISCUSSION}

Studies in the literature show that teachers' use of GIS in geography courses positively increases student and teacher motivation (Heafner, 2004; Lee and Bednarz, 2009; Özgen and Çakıcıoğlu, 2009). However, it should also be emphasized that even in developed countries that integrate GIS into the high school curriculum, the use of this technology is utilized much less than expected. It is possible to say that there is a similar situation in Turkey. We believe that the GIS-based IST program, which is carried out to encourage the use of GIS, will have an important role in solving this problem. However, in Turkey, the number of teachers who have a negative perception of IST is not little at all. Therefore, the desired efficiency cannot be obtained from the IST courses (Gültekin and Çubukçu, 2008; Uçar and İpek, 2006). Reasons such as not conducting a needs analysis and not taking volunteering as a principle stand out as some of the negative attitudes that emerge. Researchers stated that the content of the IST must meet the needs of teachers in order to be effective (Şenel, 2008; Metin, 2010; Çınar, 2011). In order to discuss the outputs of this study within the abovementioned context, we need to address questions such as "What are the advantages, as well as limitations and possible solution suggestions of this study, each step of which was planned in cooperation with teachers who have similar characteristics?". In the following section, we will address this question and relate it to other authors' discussions.

\section{Benefits}

Spatial technologies have an interdisciplinary use. Considering that the users of such technologies will differ in line with the purpose, it is better the training for such technologies should be given by educators in the same field. Indeed, the participants of this study expressed similar opinions.

The use of open source GIS software and free data in education is seen as another advantage. Especially in developing countries such as Turkey, the budget allocated for educational activities is limited. In order to eliminate this problem, teachers should be able to access educational materials free of charge. Similar to the findings of this study, the findings of the studies conducted by Fleischmann (2016) and Fleischmann and Westhuizen (2017) in South Africa, suggest that among the reasons limiting the geography teachers' use of GIS are inability to access free data, limited availability of 
useful GIS data, high prices of software, and use of other complex software. Tsou and Smith (2011) emphasized that private companies such as ESRI, Microsoft, and Intergraph played an important role in the development of GIS in the past, but nowadays, open-source GIS software is more convenient and GIS trainers will soon realize this.

We believe that the C-TPACK model-based IST program offers several advantages. Undoubtedly, technology cannot be handled independently from pedagogy and content in today's geography courses. We advocate that geography courses should be taught using an approach that combines these three variables. However, teachers' command of technology is weaker than of pedagogy and content knowledge. Indeed, Doğru and Aydın (2017) found in their study that geography teachers' pedagogy knowledge levels differed, that their technical knowledge was insufficient, and among the three variables, their field knowledge levels were highest compared to the other two variables. In line with the participants' opinions, it can be said that mastering three variables together will enrich the IST experience and will positively affect teachers' attitudes towards the use of GIS in geography courses.

\section{Limitations and Possible Solutions}

We believe that, in order for GIS to be used by geography teachers in a widespread manner, necessary infrastructure and feasibility work should be done and technical knowledge deficiencies should be eliminated. In our study, we concluded that the necessary physical infrastructure for the use of GIS has not been established yet, the technical knowledge of the teachers is insufficient, and the attitude of the school administrators towards this technology is not positive. Indeed, Ye, Brown and Harding (2014) concluded in their studies that content, insufficient software, lack of reliable data and technical knowledge, and negative attitudes of school administrators present obstacles towards the use of GIS. Although additional reasons were mentioned in the literature, it can be said that teachers cannot overcome the obstacles towards properly using GIS.

In Turkey, IST is carried out for one week in the middle of each term. We attach importance to the voluntary participation in these courses, which last ten days a year. The participants stated that they involuntarily attended ISTs that are not related to their field. Such situations negatively affect teachers' motivation and the desired efficiency cannot not be obtained from ISTs. In order to overcome the obstacles towards effective ISTs, needs analysis should be made and the training program should be planned in line with the needs of the participants. We even observed that teachers were prejudiced against IST due to their involuntary participation in previous trainings. Establishing strong communication with the sample group, meeting their different program-related needs (food and beverage, etc.), and the organization of the training by academics of the field significantly contribute to the creation of a friendly atmosphere.

\section{References}

Artvinli, E. (2010). Coğrafya'da Öğretmen Eğitimi: Hizmet Öncesi-Hizmet içi Eğitim ihtiyaç Analizi. Ankara: Pegem Publication.

Babacan, ş. \& Özey, R. (2016). In-service training needs of geography teachers. Marmara Coğrafya Dergisi, 33(1), 1-24. https://doi.org/10.14781/mcd.17180

Balcı, A. (2012). A qualitative study on teaching geographical features of Turkey with descriptive activities. Marmara Coğrafya Dergisi, 26, $215-$ 258.

Bednarz, S. W. (2004). Geographic information systems: A tool to support geography and environmental education? GeoJournal, 60(2), 191199.

Chunling, G. (2015). Need analysis and curriculum design in business English. Studies in English Language Teaching, 3(2), $146-152$.

Çınar, S. (2011). Sını öğretmenleri için Fen-Teknoloji-Toplum (FTT) yaklaşımına yönelik bir HiE kurs programı geliştirilmesi ve etkililiğinin araştırılması. (Doctoral thesis, Institute of Natural Sciences, Karadeniz Technical University, Trabzon).

Dick, W. \& Carey, L. (1978). The Systematic Design of Instruction. New York: HarperCollins.

Doering, A. \& Veletsianos, G. (2007). Multi-scaffolding environment: an analysis of scaffolding and its impact on cognitive load and problemsolving ability. Journal of Educational Computing Research, 37(2), 107-129. https://doi.org/10.2190/Q58T-4388-8015-8141

Doering, A. \& Veletsianos, G. (2008). An investigation of the use of real-time, authentic geospatial data in the K-12 classroom. Journal of Geography, 106(6), 217-225. https://doi.org/10.1080/00221340701845219

Doering, A., Koseoglu, S., Scharberg, C., Henrickson, J. \& Lanegran, D. (2014). Technology integration in K-12 geography education using TPACK as a conceptual model. Journal of Geography, 113(6), 223-237. https://doi.org/10.1080/00221341.2014.896393.

Doğru, E. \& Aydın, F. (2017). Examining the skills of geography teachers' technological pedagogical content knowledge. Journal of History Culture and Art Research, 6(2), 485-506. https://doi.org/10.7596/taksad.v6i2.686

Favier, T. T. \& van der Schee, J. A. (2014). The effects of geography lessons with geospatial technologies on the development of high school students' relational thinking. Computers \& Education, 76, 225-236. https://doi.org/10.1016/j.compedu.2014.04.004

Fleischmann, E. M. L. \& Van der Westhuizen, C. P. (2017). The interactive-GIS-Tutor (IGIST): an option for GIS teaching in resource-poor South African schools. South African Geographical Journal, 99(1), 68-85. https://doi.org/10.1080/03736245.2016.1208576

Fleischmann, E. M. L. (2016). A framework for Interactive-GIS-Tutor Integration within FET phase geography. (Doctoral thesis, Potchefstroom Campus of the North West University, South Africa).

Gültekin, M. \& Çubukçu, Z. (2008). Perceptions of primary school teachers about in-service training. Manas Üniversitesi Sosyal Bilimler Dergisi, 19(3), 185-201. 
Güven, D. (2010). Profesyonel bir meslek olarak Türkiye'de öğretmenlik. Boğaziçi Üniversitesi Eğitim Dergisi, $27(2), 13-21$.

Heafner, T. (2004). Using technology to students to learn social studies. Contemporary Issues in Technology and Teacher Education, 4(1), 4253.

Hong, J. E. (2015). Teaching GIS and other geospatial technologies to in-service teachers. In M. Solari, A. Demirci \& J. V. D. Schee (Eds.), Geospatial technologies and geography education in a changing world (pp. 117-126). New York: Springer.

Hong, J. U. \& Stonier, F. (2015). GIS in-service teacher training based on TPACK. Journal of Geography, $114(3)$, 108-117. https://doi.org/10.1080/00221341.2014.947381

Jekel, T. (2008). What you all want is GIS 2. 0. In A. Car, G. Griesebner \& J. Strobl (Eds.), Collaborative GI based learning environments: Spatial planning and education. Wichmann: Heidelberg

Johannson, T. (2006). GISAS Project: Geographical Information Systems Applications for Schools. Helsinki: University of Helsinki.

Kabakçı Yurdakul, I. (2011). Examining technopedagogical knowledge competencies of preservice teachers based on ICT usage. Hacettepe Üniversitesi Eğitim Fakültesi Dergisi, 40, 397-408.

Kaleli Yılmaz, G. (2015). Analysis of technological pedagogical content knowledge studies in Turkey: a meta-synthesis study. Education and Science, 40(178), 103-122. http://dx.doi.org/10.15390/EB.2015.4087

Kerski, J. J. (2008). The role of GIS in digital earth education. International Journal of Digital Earth, 1(4), 326-346. https://doi.org/10.1080/17538940802420879

Lee, J. \& Bednarz, R. (2009). Effect of GIS learning on spatial thinking. Journal of Geography in Higher Education, 33(2), 183-198. https://doi.org/10.1080/03098260802276714

MEB, (2021, October 07). Teacher training and development general directorate. Retrieved October 07, 2021, from http://oygm.meb.gov.tr/www/tanitim/icerik/7

Metin, M. (2010). Fen ve teknoloji öğretmenleri için hazırlanan performans değerlendirmeye yönelik hizmet içi eğitim kursunun etkililiği. (Doctoral thesis, Institute of Natural Sciences, Karadeniz Technical University, Trabzon).

Metoyer, S. (2014). Geospatial technology to enhance spatial thinking and facilitate processes of reasoning. (Doctoral thesis, Graduate and Professional Studies of Texas, A\&M University).

Metoyer, S. K., Bednarz, S. W. \& Bednarz, R. S. (2015). Spatial thinking in education: Concepts, development, and assessment. In M. Solari, A. Demirci \& J. V. D. Schee (Eds.), Geospatial technologies and geography education in a changing world (pp. 21.33). New York: Springer.

Miles, M. B. \& Huberman, A. M. (1984). Qualitative Data Analysis A Sourcebook of New Methods. Thousand Oaks: Sage Publications.

Milson, A. J. \& Roberts, J. A. (2008). The status of geospatial technologies in US high school geography standards. In A. J. Milson \& M. Alibrand (Eds.), Digital geography: Geospatial technologies in the social studies classroom (pp. 39.59). Information Age Publishing.

Mishra, P. \& Koehler, M. J. (2006). Technological pedagogical content knowledge: a framework for teacher knowledge. Teachers College Record, 108(6), 1017-1054.

Ng, W. (2012). Can we teach digital natives digital literacy? Computers \& Education, 59(3), 1065-1078. https://doi.org/10.1016/j.compedu.2012.04.016

Nielsen, C. P., Oberle, A. \& Sugumaran, R. (2011). Implementing a high school level geospatial technologies and spatial thinking course. Journal of Geography, 110(2), 60-69. https://doi.org/10.1080/00221341.2011.534171

Özgen, N. \& Çakıcıoğlu, R. O. (2009). Coğrafi bilgi sistemlerinin (CBS) Coğrafya eğitiminde kullanımı ve dersin hedeflerine ulaşma düzeyine etkisi. Ahi Evran Üniversitesi Kırşehir Eğitim Fakültesi Dergisi (KEFAD), 10(1), 81-90.

Öztürk, M. \& Eroğlu, E. (2013). Coğrafya öğretmen yeterlikleri ve uygulamaların değerlendirilmesi. Marmara Coğrafya Dergisi, 27(1), 630-659.

Patterson, M. W., Reeve, K. \& Page, D. (2003). Integrating geographic information systems into the secondary curricula. Journal of Geography, 102(6), 275-281. https://doi.org/10.1080/00221340308978559

Rossetto, R., De Filippis, G., Borsi, L., Foglia, L., Cannata, M., Criollo., R. \& Vázquez-Suñé, E. (2018). Integrating free and open source tools and distributed modelling codes in GIS environment for data-based groundwater management. Environmental Modelling \& Software, 107, 210-230. https://doi.org/10.1016/j.envsoft.2018.06.007

Şenel, T. (2008). Fen ve teknoloji öğretmenleri için alternatif ölçme ve değerlendirme tekniklerine yönelik bir hizmet içi eğitim programının etkililiğinin araştırılması. (Master thesis, Institute of Natural Sciences, Karadeniz Technical University, Trabzon).

Shulman, L. S. (1986). Those who understand: Knowledge growth in teaching. Educational Researcher, 15(2), 4-14. https://doi.org/10.3102/0013189x015002004

Shulman, L. S. (1987). Knowledge and teaching: Foundations of the new reform. Harvard Educational Review, 57(1), 1-22. https://doi.org/10.17763/haer.57.1.j463w79r56455411

Tsou, M. H. \& Smith, J. (2011). Free and Open Source software for GIS education. San Diego.

Uçar, R. \& İpek, C. (2006). İlköğretim okullarında görev yapan yönetici ve öğretmenlerin MEB hizmet içi eğitim uygulamalarına ilişkin görüşleri. Yüzüncü Yıl Üniversitesi Eğitim Fakültesi Dergisi, 3(1), 34-53.

Uşak, M. (2009). Preservice science and technology teachers' pedagogical content knowledge on cell topics. Educational Sciences: Theory and Practice, 9(4), 2033-2046.

Yazıcı, Ö. \& Gündüz, Y. (2011). Gelişmiş bazı ülkeler ile Türkiye'deki öğretmenlerin hizmet içi eğitimlerinin karşılaştırılması. Kuramsal Eğitim Bilim Dergisi, 4(2), 1-15.

Ye, H., Brown, M. \& Harding, J. (2014). GIS for all exploring the barriers and opportunities for underexploited GIS applications. OSGeo Journal, 13(1), 19-28.

Yıldırım, A. \& Şimşek, H. (2016). Sosyal Bilimlerde Nitel Araştırma Yöntemleri. Ankara: Seçkin Publication. 
APPENDIX A: Semi-structured interview questions asked for needs analysis stage

1. Do you use GIS? What do you think about the relationship between GIS and geography lessons? Drill Questions: In terms of requiring GIS in geography lessons, providing benefits, disadvantages, activities that can be done in geography lessons...

2. What do you think about the in-service training course will be developed based on the G-TPACK model? Drill Questions: In terms of advantages, disadvantages, combining pedagogical and technical knowledge into content knowledge.

3. What do you think about using free GIS software and free data in the in-service training program? Drill Questions: In terms of advantages, disadvantages, difficulties you encounter in using the software that is paid, and free education tool.

4. Which subjects students need GIS more in geography lessons?

Drill Questions: In terms of the reasons, subjects they have more problems in learning, and students' interest through maps.

5. In order to make the course program more useful;

a. What do you think about the time of the course?

b. What do you think about the location of the course?

c. What do you think about the theory and practices? 